\title{
Polymorphisms in MMP-1, MMP-2, MMP-7, MMP-13 and MT2A do not contribute to breast, lung and colon cancer risk in polish population
}

Katarzyna Białkowska ${ }^{1 *}$ D, Wojciech Marciniak², Magdalena Muszyńska², Piotr Baszuk', Satish Gupta², Katarzyna Jaworska-Bieniek', Grzegorz Sukiennicki ${ }^{1}$, Katarzyna Durda ${ }^{1}$, Tomasz Gromowski ${ }^{1}$, Marcin Lener ${ }^{1}$, Karolina Prajzendanc ${ }^{1}$, Alicja Łukomska', Cezary Cybulski ', Tomasz Huzarski ${ }^{1}$, Jacek Gronwald ${ }^{1}$, Tadeusz Dębniak', Jan Lubiński ${ }^{1,2}$ and Anna Jakubowska ${ }^{1,4}$

\begin{abstract}
Background: Matrix metalloproteinases (MMPs) and metallothioneins (MTs) are Zinc-related proteins which are involved in processes crucial for carcinogenesis such as angiogenesis, proliferation and apoptosis. Several single nucleotide polymorphisms (SNPs) in MMPs and MTs that affect genes expression have been associated with cancer risk, including breast, lung and colon.

Methods: The study group consisted of 648 unselected patients (299 with breast cancer, 199 with lung cancer, 150 with colon cancer) and 648 unaffected individuals. Five SNPs, rs1799750 in MMP-1, rs243865 in MMP-2, rs 11568818 in MMP-7, rs2252070 in MMP-13 and rs28366003 in MT2A were genotyped and serum zinc (Zn) level was measured. The cancer risk was calculated using multivariable logistic regression with respect to Zn.

Results: None of the 5 tested polymorphisms showed a correlation with cancer risk in studied groups, although for MMP-2, MMP-7 and MT2A non-significant differences in genotypes frequencies among cases and controls were observed.

Conclusions: Analyses of polymorphisms, rs1799750 in MMP-1, rs243865 in MMP-2, rs11568818 in MMP-7, rs2252070 in MMP-13 and rs28366003 in MT2A in relation to serum Zn level did not show significant association with breast, lung and colon cancer risk among polish patients. Further studies are needed to verify this observation.
\end{abstract}

Keywords: Prostate cancer, Matrix metalloproteinases, Metallothioneins, Polymorphisms

\section{Background}

Matrix metalloproteinases (MMPs) are a large family of zinc $(\mathrm{Zn})$ containing enzymes which participate in degradation and remodeling of extracellular matrix (ECM) [1]. MMPs are involved in regulation of activity of

\footnotetext{
* Correspondence: kkaczm@pum.edu.pl

'Department of Genetics and Pathology, International Hereditary Cancer Center, Pomeranian Medical University, Szczecin, Poland

Full list of author information is available at the end of the article
}

growth factors, chemokines, cytokines, and other bioactive molecules, thus participate in cell adhesion, proliferation, angiogenesis or apoptosis [2]. Impaired expression of MMPs was reported in various cancers, including breast, colon, esophagus, lung and prostate [38]. Upregulation of MMPs in cancer tissue was shown to correlate with breast tumour progression [9], and poor prognosis $[10,11]$, as well as low survival rate in breast, colon and lung cancer $[8,12,13]$.

\section{BMC}

(c) The Author(s). 2020 Open Access This article is licensed under a Creative Commons Attribution 4.0 International License, which permits use, sharing, adaptation, distribution and reproduction in any medium or format, as long as you give appropriate credit to the original author(s) and the source, provide a link to the Creative Commons licence, and indicate if changes were made. The images or other third party material in this article are included in the article's Creative Commons licence, unless indicated otherwise in a credit line to the material. If material is not included in the article's Creative Commons licence and your intended use is not permitted by statutory regulation or exceeds the permitted use, you will need to obtain permission directly from the copyright holder. To view a copy of this licence, visit http://creativecommons.org/licenses/by/4.0/ The Creative Commons Public Domain Dedication waiver (http://creativecommons.org/publicdomain/zero/1.0/) applies to the data made available in this article, unless otherwise stated in a credit line to the data. 
Metallothioneins (MTs) are group of proteins involved in storage and transport of metals such as $\mathrm{Zn}$, copper and selenium [14, 15]. The property to bind above metals enables MTs to participate in cell growth regulation, proliferation and apoptosis [16]. MTs have also high affinity to bind heavy metals such as cadmium and mercury, thus play a role in protection against toxicity of these metals [14]. The ability to bind reactive oxygen species prevents cells from oxidative DNA damage [17]. Increased MTs levels in cancer cells affect expression of various proteins including p53, caspases, FGF, VEGF, thus may inhibit apoptosis $[18,19]$ and enhance angiogenesis [20]. Similarly to MMPs, higher expression of MTs in tumors has been shown to correlate with high grade [21] and relapse [22] in breast cancer, as well as progression [23] and low survival [24] in lung cancer patients.

Both MMPs and MTs are Zn-related proteins. MMPs require $\mathrm{Zn}$ ions to maintain their structure and functions [1]. MTs are involved in regulation of $\mathrm{Zn}$ homeostasis through binding and storing excessive $\mathrm{Zn}$ ions when cytosolic $\mathrm{Zn}$ level is increased and releasing it in case of $\mathrm{Zn}$ deficiency $[15,25] . \mathrm{Zn}$ is one of the most important micronutrient involved in many processes in human body [26] and disruptions in its homeostasis have been linked to several diseases [27-32] including cancers [33-40].

Several single nucleotide polymorphisms (SNPs) in promoter regions of MMPs and MTs genes have been reported to affect gene's expression [41-46]. Previous reports indicate that SNPs in MMPs and MTs genes may be associated with risk of cancers. Five SNPs, rs1799750 in $M M P-1$, rs243865 in $M M P-2$, rs11568818 in MMP-7, rs2252070 in $M M P-13$ and rs28366003 in $M T 2 A$ has been studied in various cancers including breast [4757], lung [47, 58-64] and colon cancer [44, 47, 65-75], but results were ambiguous. The results of metaanalyses suggest that polymorphisms in MMP-1, MMP2, and MMP-7 may be associated with cancer risk in Asian or Latin-American populations, but not in European or Caucasian populations [63, 76-80]. The MMPs and MTs are strongly associated with Zn homeostasis, so it is highly probable that the influence of SNPs in these genes on cancer risk may be dependent on $\mathrm{Zn}$ status. Therefore, it seems highly reasonable to perform multivariable logistic regression analysis to evaluate the association of SNPs in MMPs and MTs together with serum $\mathrm{Zn}$ levels with cancer risk. However, such analyses have been not performed to date in any of the previous studies.

The aim of this study was to investigate association of polymorphisms $\mathrm{rs} 1799750$ in $M M P-1, \quad$ rs243865 in $M M P-2$, rs11568818 in $M M P-7$, rs 2252070 in $M M P-13$ and rs28366003 in $M T 2 A$, together with serum Zn level, with occurrence of breast, lung and colon cancer in Poland.

\section{Material and methods Study participants}

Study group consisted of 648 unselected patients among whom 299 were diagnosed with breast cancer, 199 with lung cancer and 150 with colon cancer. All patients were diagnosed between 2010 and 2014 at the Clinical Hospital No 2. in Szczecin, had no previous history of malignancy and were not treated prior to blood collection. To each case was matched one cancer free control selected among individuals who took part in a population-based screening study performed in the West-Pomeranian region of Poland to identify familial cancer syndromes. Controls were matched to cases with respect to sex, year of birth (+/- 3 years), occurrence of malignancies among first degree relatives, smoking (status and number of pack/years) and adnexectomy status (for group of breast cancer patients). The characteristics of study groups and controls are shown in Table 1. From all participants enrolled in the study informed written consent for the use of their samples in research was obtained. The study was approved by Ethics Committee of the Pomeranian Medical University in Szczecin, Poland.

\section{Laboratory analyses}

From each person included in the study two peripheral blood samples were collected, one to obtain serum for $\mathrm{Zn}$ measurement and second for isolation of genomic DNA. The methods of samples preparation were described previously [81].

Laboratory analyses encompassed measurement of $\mathrm{Zn}$ in serum and genotyping of 5 SNPs: rs1799750 in MMP1, rs243865 in $M M P-2$, rs11568818 in $M M P-7$, rs2252070 in $M M P-13$ and rs28366003 in $M T 2 A$, as described previously [81].

\section{Statistical analysis}

Comparison of characteristics between cases and controls was performed using Mann-Whitney U-test. Association of tested SNPs with cancer risk was established by comparing the frequencies of genotypes among patients and healthy individuals in each cancer group. The most frequent homozygous genotype of the analyzed SNP was considered as a 'reference'. The odds ratios (ORs) and corresponding 95\% confidence intervals (95\% CI) for each tested SNP were calculated using multivariable logistic regression model and adjusted for serum $\mathrm{Zn}$ level. Analyses were performed using R Project for Statistical Computing (ver. 3.3.3.). 
Table 1 Characteristic of cases and controls included in the study

\begin{tabular}{|c|c|c|c|}
\hline \multicolumn{4}{|l|}{ Breast cancer group } \\
\hline Characteristic & Cases $(n=299)$ & Controls $(n=299)$ & $p$-value* \\
\hline Mean year of birth (range) & 1953 (1923-1989) & 1953 (1923-1990) & 0.93 \\
\hline \multicolumn{4}{|l|}{ Smoking, n (\%) } \\
\hline Yes (current + past) & 129 & 129 & - \\
\hline No (never smokers) & 170 & 170 & - \\
\hline Pack-years (range) & $6.61(0-40)$ & $6.64(0-50)$ & 0.49 \\
\hline \multicolumn{4}{|l|}{ Adnexectomy status, n (\%) } \\
\hline Yes & 15 & 15 & - \\
\hline No & 284 & 284 & - \\
\hline \multicolumn{4}{|c|}{ Occurrence of breast cancer among $1^{\circ}$ relatives, $\mathrm{n}(\%)$} \\
\hline Yes & 39 & 41 & - \\
\hline No & 260 & 258 & - \\
\hline \multicolumn{4}{|l|}{ Lung cancer group } \\
\hline Characteristic & Cases $(n=199)$ & Controls $(n=199)$ & $p$-value ${ }^{*}$ \\
\hline Mean year of birth (range) & 1947 (1928-1977) & 1947 (1931-1976) & 0.62 \\
\hline \multicolumn{4}{|l|}{ Sex, n (\%) } \\
\hline Females & 51 & 51 & - \\
\hline Males & 148 & 148 & - \\
\hline \multicolumn{4}{|l|}{ Smoking, n (\%) } \\
\hline Yes (current + past) & 188 & $183^{* *}$ & - \\
\hline No (never smokers) & 11 & $16^{* *}$ & - \\
\hline Pack-years (range) & $30.14(0-150)$ & $29.72(0-150)$ & 0.50 \\
\hline \multicolumn{4}{|c|}{ Occurrence of lung cancer among $I^{\circ}$ relatives, $\mathrm{n}(\%)$} \\
\hline Yes & 37 & 30 & - \\
\hline No & 162 & 169 & - \\
\hline \multicolumn{4}{|l|}{ Colon cancer group } \\
\hline Characteristic & Cases $(n=150)$ & Controls $(n=150)$ & $p$-value ${ }^{*}$ \\
\hline Mean year of birth (range) & 1947 (1924-1985) & 1947 (1927-1984) & 0.99 \\
\hline \multicolumn{4}{|l|}{ Sex, n (\%) } \\
\hline Females & 58 & 58 & - \\
\hline Males & 92 & 92 & - \\
\hline \multicolumn{4}{|l|}{ Smoking, n (\%) } \\
\hline Yes (current + past) & 95 & $94^{* *}$ & - \\
\hline No (never smokers) & 55 & $56^{* *}$ & - \\
\hline Pack-years (range) & $14.2(0-90)$ & $14.1(0-80)$ & 0.30 \\
\hline \multicolumn{4}{|c|}{ Occurrence of colon cancer among $\mathrm{I}^{\circ}$ relatives, $\mathrm{n}(\%)$} \\
\hline Yes & 17 & 16 & - \\
\hline No & 133 & 134 & - \\
\hline
\end{tabular}

* $p$-value calculated using Mann-Whitney Test

${ }^{* *}$ controls smoking $<1$ year were matched to never smoking cases

\section{Results}

None of the 5 tested polymorphisms showed a correlation with cancer risk in studied groups, although some non-significant differences in genotypes frequencies among cases and controls were observed for $M M P-2$,
$M M P-7$ and $M T 2 A . M M P-2$ TT genotype was less frequent among breast cancer patients comparing to controls $(4.3 \%$ vs $8.4 \%)$ (Table 2), but more frequent in lung cancer cases (5\% in cases vs $3 \%$ in controls) (Table 3$)$. In colon cancer group we observed that MMP-7 GG 
Table 2 Association of analyzed SNPs with breast cancer risk

\begin{tabular}{|c|c|c|c|c|}
\hline Genotype & Cases, $\boldsymbol{n}=299(\%)$ & Controls, $\boldsymbol{n}=299(\%)$ & $\mathrm{OR}^{\mathbf{a}}(95 \% \mathrm{Cl})$ & $p$-value \\
\hline \multicolumn{5}{|c|}{ MMP-1 (rs1799750) } \\
\hline $1 \mathrm{G} / 1 \mathrm{G}$ & $80(26.8)$ & $80(26.8)$ & 1 & - \\
\hline $1 \mathrm{G} / 2 \mathrm{G}$ & $140(46.8)$ & $144(48.2)$ & $1.01(0.68-1.46)$ & 0.99 \\
\hline $2 \mathrm{G} / 2 \mathrm{G}$ & $79(26.4)$ & $75(25.1)$ & $1.08(0.70-1.67)$ & 0.73 \\
\hline \multicolumn{5}{|c|}{ MMP-2 (rs243865) } \\
\hline $\mathrm{CC}$ & $172(57.5)$ & $169(56.5)$ & 1 & - \\
\hline $\mathrm{CT}$ & $114(38.1)$ & $105(35.1)$ & $1.08(0.77-1.51)$ & 0.66 \\
\hline$\pi$ & $13(4.3)$ & $25(8.4)$ & $0.56(0.28-1.11)$ & 0.10 \\
\hline \multicolumn{5}{|c|}{ MMP-7 (rs11568818) } \\
\hline $\mathrm{AA}$ & $106(35.5)$ & $93(31.1)$ & 1 & - \\
\hline$A G$ & $151(50.5)$ & $152(50.8)$ & $0.87(0.61-1.24)$ & 0.44 \\
\hline GG & $42(14)$ & $54(18.1)$ & $0.68(0.42-1.10)$ & 0.11 \\
\hline \multicolumn{5}{|c|}{$M M P-13$ (rs2252070) } \\
\hline AA & $142(47.5)$ & $146(48.8)$ & 1 & - \\
\hline$A G$ & $133(44.5)$ & $125(41.8)$ & $1.12(0.79-1.59)$ & 0.53 \\
\hline GG & $24(8)$ & $28(9.4)$ & $0.84(0.44-1.57)$ & 0.58 \\
\hline \multicolumn{5}{|c|}{$M T 2 A(\mathrm{rs} 28366003)$} \\
\hline AA & $274(91.6)$ & $267(89.3)$ & 1 & - \\
\hline$A G+G^{b}$ & $25(8.4)$ & $32(10.7)$ & $0.73(0.42-1.27)$ & 0.27 \\
\hline
\end{tabular}

${ }^{\mathrm{a}}$ Multivariable logistic regression adjusted for $\mathrm{Zn}$ level

${ }^{b}$ Genotypes were summarized because of low number of GG genotype

Table 3 Association of analyzed SNPs with lung cancer risk

\begin{tabular}{|c|c|c|c|c|}
\hline Genotype & Cases, $\boldsymbol{n}=199(\%)$ & Controls, $\boldsymbol{n}=199(\%)$ & $\mathrm{OR}^{\mathbf{a}}(95 \% \mathrm{Cl})$ & $\overline{p \text {-value }}$ \\
\hline \multicolumn{5}{|c|}{ MMP-1 (rs1799750) } \\
\hline $1 \mathrm{G} / 1 \mathrm{G}$ & $48(24.1)$ & $47(23.6)$ & 1 & - \\
\hline $1 \mathrm{G} / 2 \mathrm{G}$ & $114(57.3)$ & $107(53.8)$ & $0.98(0.61-1.57)$ & 0.92 \\
\hline $2 \mathrm{G} / 2 \mathrm{G}$ & 37 (18.6) & $45(22.6)$ & $0.77(0.42-1.39)$ & 0.38 \\
\hline \multicolumn{5}{|c|}{ MMP-2 (rs243865) } \\
\hline $\mathrm{CC}$ & $120(60.3)$ & $121(60.8)$ & 1 & - \\
\hline $\mathrm{CT}$ & $69(34.7)$ & $72(36.2)$ & $1.01(0.65-1.55)$ & 0.98 \\
\hline$\pi$ & $10(5)$ & $6(3)$ & $1.64(0.56-4.83)$ & 0.37 \\
\hline \multicolumn{5}{|c|}{ MMP-7 (rs11568818) } \\
\hline AA & 70 (35.2) & $71(35.7)$ & 1 & - \\
\hline$A G$ & $98(49.2)$ & $100(50.3)$ & $1.03(0.65-1.61)$ & 0.91 \\
\hline GG & $31(15.6)$ & $28(14.1)$ & $1.24(0.63-2.44)$ & 0.54 \\
\hline \multicolumn{5}{|c|}{ MMP-13 (rs2252070) } \\
\hline AA & $83(41.7)$ & $96(48.2)$ & 1 & - \\
\hline$A G$ & $99(49.7)$ & $87(43.7)$ & $1.38(0.89-2.14)$ & 0.15 \\
\hline GG & $17(8.5)$ & $16(8)$ & $1.26(0.61-2.62)$ & 0.53 \\
\hline \multicolumn{5}{|c|}{ MT2A (rs28366003) } \\
\hline AA & $174(87.4)$ & $180(90.5)$ & 1 & - \\
\hline$A G+G G^{b}$ & $25(12.6)$ & $19(9.5)$ & $1.52(0.72-3.18)$ & 0.27 \\
\hline
\end{tabular}

${ }^{a}$ Multivariable logistic regression adjusted for $\mathrm{Zn}$ level

${ }^{\mathrm{b}} \mathrm{Genotypes}$ were summarized because of low number of GG genotype 
genotype as well as MT2A AG and GG genotypes were more frequent among cases than controls ( $18 \%$ vs 13.3 and $12.7 \%$ vs $7.3 \%$, respectively) (Table 4 ).

\section{Discussion}

In the present study we analyzed whether polymorphisms rs28366003 in $M T 2 A$, rs1799750 in $M M P-1$, rs243865 in $M M P-2, \quad$ rs11568818 in $M M P-7$ and rs2252070 in $M M P-13$ genes are associated with the risk of breast, lung or colon cancer among polish subjects. Since functions of MTs and MMPs are strongly related to $\mathrm{Zn}$ homeostasis, in this study we also measured serum $\mathrm{Zn}$ level and performed multivariable analysis adjusted for $\mathrm{Zn}$ level. Results did not show any significant correlations with cancer risk in studied groups, although nonsignificant differences in genotypes frequencies among cancer cases and controls were observed for $M M P-2$ in breast and lung cancer group (Tables 2 and 3), $M M P-7$ and $M T 2 A$ in colon cancer group (Table 4).

The rs243865 $(-1306 \mathrm{C}>\mathrm{T})$ in $M M P-2$ is located in gene promoter and alters the SP-1 transcription factor binding site, resulting in reduction of protein expression [42]. Several studies have examined association of this SNP with the risk of breast, lung and colon cancers, however results were ambiguous. In 2 studies, from Mexico (90 cases and 96 controls) [52] and Saudi Arabia (90 cases and 92 controls) [51], CC genotype was associated with increased risk of breast cancer $(\mathrm{OR}=$ 2.15, $p=0.01$ and $\mathrm{OR}=2.02, p=0.02$ respectively). In analysis of 462 cases and 509 controls from China [50], the $\mathrm{T}$ allele was shown to have a protective effect on breast cancer $(\mathrm{OR}=0.46, p<0.001)$. On a contrary, in Greek (113 cases and 124 controls) [53], Brazilian (89 cases and 100 controls) [54] and Swedish (959 cases and 952 controls) [48] studies no association between rs243865 and breast cancer risk was shown. Results of meta-analysis encompassing 9858 cases and 10,871 controls suggest that rs 243865 CC genotype is associated with an increased risk of breast cancer only in Latin American population, but not European and Asian [76]. Although in our study we did not found a significant correlation of rs243865 in $M M P-2$ with breast cancer risk, the TT genotype found to be less frequent among cases than in controls $(4,3 \%$ vs. $8.4 \%$, Table 2$)$, what is consistent with the previous findings [50-52]. Analyzes of rs243865 in MMP-2 in 2 studies conducted in Saudi Arabia comprising 220 cases and 247 controls revealed positive correlation of TT genotype with 6.5 - fold increased risk of colon cancer [67, 71]. However, results of 3 other studies performed in Chinese, Swedish and Korean populations did not confirm this observation [68-70]. Association of rs243865 with 2-fold increased lung cancer risk was observed in 2 Chinese analyses encompassing of 781 cases, 852 controls (OR 2.18; 95\%

Table 4 Association of analyzed SNPs with colon cancer risk

\begin{tabular}{|c|c|c|c|c|}
\hline Genotype & Cases, $\boldsymbol{n}=150(\%)$ & Controls, $\boldsymbol{n}=150(\%)$ & $\mathrm{OR}^{\mathbf{a}}(95 \% \mathrm{Cl})$ & $\boldsymbol{p}$-value \\
\hline \multicolumn{5}{|c|}{ MMP-1 (rs1799750) } \\
\hline $1 \mathrm{G} / 1 \mathrm{G}$ & $38(25.3)$ & 49 (32.7) & 1 & - \\
\hline $1 \mathrm{G} / 2 \mathrm{G}$ & $75(50)$ & $66(44)$ & $1.49(0.87-2.55)$ & 0.15 \\
\hline $2 \mathrm{G} / 2 \mathrm{G}$ & $37(24.7)$ & $35(23.3)$ & $1.34(0.70-2.56)$ & 0.37 \\
\hline \multicolumn{5}{|c|}{ MMP-2 (rs243865) } \\
\hline CC & $88(58.7)$ & $88(58.7)$ & 1 & - \\
\hline CT & $53(35.3)$ & $54(36)$ & $1.01(0.59-1.67)$ & 0.99 \\
\hline$\pi$ & $9(6)$ & $8(5.3)$ & $1.27(0.46-3.52)$ & 0.65 \\
\hline \multicolumn{5}{|c|}{ MMP-7 (rs11568818) } \\
\hline AA & $52(34.7)$ & $53(35.3)$ & 1 & - \\
\hline$A G$ & $71(47.3)$ & $77(51.3)$ & $0.96(0.56-1.65)$ & 0.90 \\
\hline GG & $27(18)$ & $20(13.3)$ & $1.41(0.66-2.99)$ & 0.38 \\
\hline \multicolumn{5}{|c|}{ MMP-13 (rs2252070) } \\
\hline AA & $79(52.7)$ & $70(46.7)$ & 1 & - \\
\hline$A G$ & $60(40)$ & $70(46.7)$ & $0.78(0.50-1.24)$ & 0.30 \\
\hline GG & $11(7.3)$ & $10(6.7)$ & $0.95(0.34-2.64)$ & 0.92 \\
\hline \multicolumn{5}{|c|}{ MT2A (rs28366003) } \\
\hline $\mathrm{AA}$ & $131(87.3)$ & $139(92.7)$ & 1 & - \\
\hline$A G+G G^{b}$ & 19 (12.7) & $11(7.3)$ & $1.76(0.81-3.83)$ & 0.15 \\
\hline
\end{tabular}

${ }^{a}$ Multivariable logistic regression adjusted for $\mathrm{Zn}$ level

${ }^{\mathrm{b}}$ Genotypes were summarized because of low number of GG genotype 
CI 1.70-2.79) and 770 cases, 777 controls (OR 2.12; 95\% CI 1.64-2.72) [59, 60]. Although, in 2 other studies, from France (90 cases and 90 controls) [61] and Turkey (200 cases and 100 controls) [62], no correlation with lung cancer risk was observed. Results of 2 metaanalyzes indicate that rs243865 in $M M P-2$ correlates with lung cancer risk in Asian populations, but not Caucasians [77, 78]. In our study we did not detect significant association of rs243865 in $M M P$-2 with lung and colon cancer risk, however we observed higher frequency of TT genotype in lung cancer patients comparing to controls (5\% vs. $3 \%$, Table 3 ).

The SNP rs11568818 $(-181 \mathrm{~A}>\mathrm{G})$ in $M M P-7$ gene has been shown to affect gene expression and $G$ allele was found to upregulate the transcription [43, 82]. The rs11568818 has been analyzed previously in relation to colon, lung and breast cancers, but results were inconclusive. In a Polish study encompassing 184 cases and 205 controls, the GG genotype was more frequent among cancer patients than healthy individuals $(28 \%$ vs. $22 \%$ ) and correlated with 2-times increased colon cancer risk $(\mathrm{OR}=2.12, p=0.018)$ [73]. Accordant results were presented in Italian study of 58 cases and 118 controls showing similarly higher frequency of GG in cancer patients comparing to controls (26\% vs. $13 \%)$ and association of GG with almost 2.5-time higher colon cancer risk $(\mathrm{OR}=2.41 ; p=0.03)$ [72]. On a contrary, in a Brazilian study of 130 colon cancer cases and 130 controls, no association of rs11568818 in MMP-7 with colon cancer risk was shown [74]. In our analysis of 150 colon cancer cases and 150 controls we did not detect a significant association of the rs11568818 with cancer risk, however we observed higher frequency of GG genotype in cancer patients than in healthy individuals (18\% vs. $13.3 \%$, Table 4), what is consistent with previous Polish [73] and Italian [72] observations. Analyses of rs11568818 in MMP-7 performed in Chinese population suggested that rs11568818 may correlate with 2-fold increased risk of lung cancer (243 cases and 350 controls, $\mathrm{OR}=2.0,95 \% \mathrm{CI}=1.23-3.24$ for AG and GG genotypes) [83], but not breast cancer (1079 cases and 082 controls) [55]. A meta-analysis of 24 studies encompassing 12 populations and including 10 different cancer sites revealed that MMP-7 SNP may be associated with the risk of various cancers, including gastric, colon, liver, bladder, cervix, ovary, breast, brain and lung, but only in Asian population $(\mathrm{OR}=2.18,95 \% \mathrm{CI} 1.68-2.84)$ and not European $(\mathrm{OR}=1.07,95 \%$ CI 0.6-1.89) [79]. In our analysis the rs11568818 was not associated with the risk of breast and lung cancers.

The promoter polymorphism rs28366003 $(-5 \mathrm{~A}>\mathrm{G})$ in $M T 2 A$ gene is suggested to reduce the heavy metal induced MT2A transcription, what could result in increased toxicity of heavy metals $[45,46]$. Several analyzes suggested that, the rs 28366003 in MT2A correlates with breast cancer risk. In a Polish study including 534 cases and 556 controls rs 28366003 was shown to be associated with almost 2-fold increased cancer risk for AG-heterozygotes and GG-homozygotes $(\mathrm{OR}=1.93 ; p=$ 0.02) [56]. Similarly in a Chinese study conducted in a group of 459 breast cancer patients and 549 controls, rs28366003 was found to correlate with over 2-fold higher breast cancer risk for AG and GG genotypes $(\mathrm{OR}=2.66, p<0.0001)$ [57]. In our study we did not detect significant correlation of rs28366003 in MT2A with breast, colon or lung cancer risk, although we observed higher frequency of AG and GG genotypes in colon and lung cancer cases in comparison to controls $(12.7 \%$ vs. 7.3 and $12.6 \%$ vs. $9.5 \%$, respectively).

The rs1799750 in MMP-1 (-1607 1G > 2G) is an insertion polymorphism located in promoter region and $2 \mathrm{G}$ allele was found to upregulate gene expression [84]. Results of 3 studies performed in Sweden (959 cases and 952 controls) [48], Italy (43 cases and 164 controls) [47] and Poland (270 cases and 300 controls) [49] showed no association of this polymorphism with breast cancer risk. Analysis performed in USA encompasing 1752 cases and 1363 controls revealed association of rs179975 with lung cancer risk but only in men and never-smokers [58]. However, Italian study of 29 cases and 164 controls did not confirm this observation [47]. Results of two separate meta-analyzes, each including 9 studies, indicated that rs1799750 in MMP-1 may be associated with lung cancer risk, but only in Asian populations [63, 80]. In two other studies, from Japan (101 cases and 127 controls) and Italy (63 cases and 164 controls), rs179975 was suggested to correlate with colon cancer risk. It was found that comparing to $1 \mathrm{G} / 1 \mathrm{G}$ genotype, $2 \mathrm{G} / 2 \mathrm{G}$ genotype was associated with 2-fold increased colon cancer risk $(\mathrm{OR}=2.08 ; p=0.007$ and $\mathrm{OR}=2.21 ; p=0.014$, respectively) $[65,66]$. However, other Italian study comprising 60 cases and 164 controls showed no association of this SNP with colon cancer [47]. In our analysis we did not observe significant association of rs1799750 in $M M P-1$ with breast, lung and colon cancer risk.

The SNP rs2252070 (-77 A > G) in MMP-13 is located in promoter region and is suggested to affect gene expression [85]. Few studies have investigated the correlation rs2252070 with cancers. No association of rs2252070 was detected with lung cancer risk in Spanish study of 501 cases and 506 controls [64], as well as with colon cancer risk in Swedish analysis of 385 cases and 619 controls [44]. On a contrary, a Mexican study encompassing 102 cases and 121 controls showed association of AA and AG genotypes with increased colon cancer risk $(\mathrm{OR}=3.4, \mathrm{p}=0.01)$ [75]. In our analysis we did not observe correlation of rs2252070 in MMP-13 with breast, lung or colon cancer risk. 
In our study of 1296 individuals including 648 cancer patients (299 diagnosed with breast cancer, 199 with lung cancer, 150 with colon cancer) and equal number of healthy controls we were unable to detect a significant correlation of polymorphisms rs1799750 in MMP-1, rs243865 in $M M P-2$, rs11568818 in $M M P-7$, rs 2252070 in $M M P-13$ and rs28366003 in $M T 2 A$ with occurrence of breast, lung and colon cancer in Poland. As functions of matrix metalloproteinases (MMP-1, MMP-2, MMP-7, $M M P-13)$ and metallothioneins $(M T 2 A)$ are strongly related to $\mathrm{Zn}$ homeostasis, we measured serum $\mathrm{Zn}$ level and performed multivariable analysis of tested SNPs adjusted for $\mathrm{Zn}$ level, which is the main advantage of our study. Such approach allowed reducing the risk of bias caused by Zn level, which might be significant factor influencing functions of MTs and MMPs and affecting cancer risk. $\mathrm{Zn}$ level was not considered in previous studies investigating association of $M M P-1, M M P-2$, $M M P-7, M M P-13$ and $M T 2 A$ polymorphism with cancer risk. In addition to tested serum $\mathrm{Zn}$ level we also used strong pairing criteria for cases and controls. To each affected individual one control was matched with respect to significant factors such birth year, family history (number of cancers in first degree relatives), smoking and adnexectomy status (in breast cancer group) to avoid influence of these factors on cancer risk.

In our study, despite the fact that sample size was larger than in several previously published analyzes [47, $51-54,61,62,65-71,75]$, we were unable to detect significant result, what could be an effect of insufficient study sample. Further studies are needed to verify association of rs1799750 in $M M P-1$, rs 243865 in $M M P-2$, rs11568818 in MMP-7, rs2252070 in $M M P-13$ and rs28366003 in $M T 2 A$ with breast, colon and lung cancers.

\section{Conclusion}

Analyses of polymorphisms rs1799750 in MMP-1, rs243865 in $M M P-2$, rs11568818 in $M M P-7$, rs2252070 in $M M P-13$ and rs28366003 in $M T 2 A$ in relation to serum $\mathrm{Zn}$ level did not show significant association of tested SNPs with breast, lung and colon cancer risk among polish patients.

\section{Abbreviations \\ SNP: Single nucleotide polymorphism; PCR: Polymerase chain reaction; MMP: Matrix metalloproteinase; MT: Metallothionein}

\section{Acknowledgements}

Not applicable.

\section{Authors' contributions}

Collected data from cancer patients - CC, TD,TH, JG; collected data from controls - KB, KJB, GS, TG, KD, KP, AŁ, ML; performed Zn measurements- WM, MM; performed molecular analyses - KB; performed statistical analyses- $\mathrm{PB}$, SG; conceived and designed the experiments- AJ, JL, KB; writing original draft of the paper- KB, AJ; All authors read and approved the final manuscript.

\section{Funding}

The project was financially supported by National Science Centre, grant no. DEC-2012/07/N/NZ4/02433. The funder did not have any additional role in the study design, data collection and analysis, decision to publish, or preparation of the manuscript. The funder Read-Gene S.A. provided support in the form of salaries for authors WM, MM, JL, but did not have any additional role in the study design, data collection and analysis, decision to publish, or preparation of the manuscript. The specific roles of these authors are articulated in the 'author contributions' section.

Availability of data and materials

All relevant data are within the paper and its supporting information files.

Ethics approval and consent to participate

All participants gave informed written consent prior blood donating. The study was approved by Ethics Committee of the Pomeranian Medical University in Szczecin, Poland.

Consent for publication

Not applicable.

\section{Competing interests}

$J$ is CEO of Read-Gene S.A. The authors WM, MM are employees of ReadGene S.A. KB, PB, SG, KJB, GS, KD, TG, ML, KP, AŁ, CC, TH, JG, TD, AJ declare that they have no competing interests.

\section{Author details}

${ }^{1}$ Department of Genetics and Pathology, International Hereditary Cancer Center, Pomeranian Medical University, Szczecin, Poland. ${ }^{2}$ Read-Gene S.A., Grzepnica, Poland. ${ }^{3}$ Strand Life Sciences, Bangalore, Karnataka, India.

${ }^{4}$ Independent Laboratory of Molecular Biology and Genetic Diagnostics, Pomeranian Medical University, Szczecin, Poland.

Received: 14 April 2020 Accepted: 24 July 2020

Published online: 31 July 2020

\section{References}

1. Jabłońska-Trypuć A, Matejczyk M, Rosochacki S. Matrix metalloproteinases (MMPs), the main extracellular matrix (ECM) enzymes in collagen degradation, as a target for anticancer drugs. J Enzyme Inhib Med Chem. 2016:31(sup1):177-83.

2. Lipka D, Boratyński J. Metalloproteinases. Structure and function. Postepy Hig Med Dosw. 2008;62:328-36.

3. Chabottaux $V$, Noel A. Breast cancer progression: insights into multifaceted matrix metalloproteinases. Clin Exp Metastasis. 2007;24(8):647-56.

4. Murray Gl, Duncan ME, Arbuckle E, et al. Matrix metalloproteinases and their inhibitors in gastric cancer. Gut. 1998;43(6):791-7.

5. Waas ET, Lomme RM, DeGroot J, et al. Tissue levels of active matrix metalloproteinase-2 and -9 in colorectal cancer. Br J Cancer. 2002;86(12): 1876-83.

6. Morgia G, Falsaperla M, Malaponte G, et al. Matrix metalloproteinases as diagnostic (MMP-13) and prognostic (MMP-2, MMP-9) markers of prostate cancer. Urol Res. 2005;33(1):44-50.

7. Ylisirniö S, Höyhtyä M, Turpeenniemi-Hujanen T. Serum matrix metalloproteinases $-2,-9$ and tissue inhibitors of metalloproteinases $-1,-2$ in lung cancer--TIMP-1 as a prognostic marker. Anticancer Res. 2000;20(2B): $1311-6$

8. Liu H, Zhang T, Li X, et al. Predictive value of MMP-7 expression for response to chemotherapy and survival in patients with non-small cell lung cancer. Cancer Sci. 2008;99(11):2185-92.

9. Kang $Y$, Siegel PM, Shu W, et al. A multigenic program mediating breast cancer metastasis to bone. Cancer Cell. 2003:3(6):537-49.

10. Boström $P$, Söderström M, Vahlberg T, et al. MMP-1 expression has an independent prognostic value in breast cancer. BMC Cancer. 2011;11:348.

11. Bin Z, Xuchen C, Yanxue L. Tumor-derived matrix metalloproteinase-3 (MMP-13) correlates with poor prognoses of invasive breastcancer. BMC Cancer. 2008;28:83-90 
12. Jinga DC, Blidaru A, Condrea I. MMP-9 and MMP-2 gelatinasesand TIMP-1 and Timp-2 inhibitors in breast cancer: correlations withprognostic factors. J Cell Mol Med. 2006;10:499-510.

13. Sun DW, Zhang YY, Qi Y, et al. Prognostic significance of MMP-7 expression in colorectal cancer: a meta-analysis. Cancer Epidemiol. 2015;39(2):135-42.

14. Thirumoorthy N, Shyam Sunder A, et al. A review of metallothionein isoforms and their role in pathophysiology. World J Surg Oncol. 2011;9:54.

15. Krezel A, Maret W. Thionein/metallothionein control Zn (II) availability and the activity of enzymes. J Biol Inorg Chem. 2008;13:401-9.

16. Si M, Lang J. The roles of metallothioneins in carcinogenesis. J Hematol Oncol. 2018 Aug 23;11(1):107.

17. Higashimoto M, Isoyama N, Ishibashi S, Inoue M, Takiguchi M, Suzuki S, Ohnishi Y, Sato M. Tissue-dependent preventive effect of metallothionein against DNA damage in dyslipidemic mice under repeated stresses of fasting or restraint. Life Sci. 2009;84(17-18):569-75.

18. Arriaga JM, Bravo IA, Bruno L, et al. Combined metallothioneins and p53 proteins expression as a prognostic marker in patients with dukes stage $B$ and C colorectal cancer. Hum Pathol. 2012;43(10):1695-703.

19. Dutsch-Wicherek M, Sikora J, Tomaszewska R. The possible biological role of metallothionein in apoptosis. Front Biosci. 2008;13:4029-38.

20. Nielsen AE, Bohr A, Penkowa M. The balance between life and death of cells: roles of Metallothioneins. Biomark Insights. 2007;1:99-111.

21. Cherian MG, Jayasurya A, Bay BH. Metallothioneins in human tumors and potential roles in carcinogenesis. Mutat Res. 2003;533(1-2):201-9.

22. Surowiak P, Materna V, Györffy B, et al. Multivariate analysis of oestrogen receptor alpha, pS2, metallothionein and CD24 expression in invasive breast cancers. Br J Cancer. 2006;95(3):339-46.

23. Dziegiel $\mathrm{P}$, Jeleń M, Muszczyńska B, et al. Role of metallothionein expression in non-small cell lung carcinomas. Rocz Akad Med Bialymst. 2004;49(Suppl 1):43-5

24. Joseph MG, Banerjee D, Kocha W, et al. Metallothionein expression in patients with small cell carcinoma of the lung: correlation with other molecular markers and clinical outcome. Cancer. 2001:92(4):836-42.

25. Bozym RA, Chimienti F, Giblin LJ, et al. Free zinc ions outside a narrow concentration range are toxic to a variety of cells in vitro. Exp Biol Med (Maywood). 2010;235(6):741-50.

26. Chasapis CT, Loutsidou AC, Spiliopoulou CA, Stefanidou ME. Zinc and human health: an update. Arch Toxicol. 2012;86(4):521-34.

27. Gammoh NZ, Rink L. Zinc in Infection and Inflammation. Nutrients. 2017: 9(6):624.

28. Little PJ, Bhattacharya R, Moreyra AE, et al. Zinc and cardiovascular disease. Nutrition. 2010;26(11-12):1050-7.

29. Shokrzadeh M, Ghaemian A, Salehifar E, et al. Serum zinc and copper levels in ischemic cardiomyopathy. Biol Trace Elem Res. 2009;127:116-23.

30. Maret W. Zinc in pancreatic islet biology, insulin sensitivity, and diabetes. Prev Nutr Food Sci. 2017;22(1):1-8.

31. Wang CY, Wang T, Zheng W, et al. Zinc overload enhances APP cleavage and $A \beta$ deposition in the Alzheimer mouse brain. PLoS One. 2010;5(12): e15349

32. Foong J, Rozewicz L, Chong WK, et al. A comparison of neuropsychological deficits in primary and secondary progressive multiple sclerosis. J Neurol. 2000;247(2):97-101.

33. Ho E, Ames BN. Low intracellular zinc induces oxidative DNA damage, disrupts p53, NFkappa B, and AP1 DNA binding, and affects DNA repair in a rat glioma cell line. Proc Natl Acad Sci U S A. 2002;99:16770-5.

34. Anguita E, Candel FJ, Chaparro A, et al. Transcription factor GFI1B in health and disease. Front Oncol. 2017;7:54

35. Zhu Z, Wang $H$, Wei $Y$, et al. Ownregulation of PRDM1 promotes cellular invasion and lung cancer metastasis. Tumour Biol. 2017;39(4): 1010428317695929.

36. Orellana-Serradell O, Herrera D, Castellon EA, et al. The transcription factor ZEB1 promotes an aggressive phenotype in prostate cancer cell lines. Asian J Androl. 2018;20(3):294-9.

37. Tapiero H, Tew KD. Trace elements in human physiology and pathology: zinc and metallothioneins. Biomed Pharmacother. 2003:57:399-411.

38. Dhawan DK, Chadha VD. Zinc: a promising agent in dietary chemoprevention of cancer. Indian J Med Res. 2010;132:676-82.

39. Li J, Li Y, Wang HL, et al. Measurement of serum zinc improves prostate cancer detection efficiency in patients with PSA levels between $4 \mathrm{ng} / \mathrm{mL}$ and $10 \mathrm{ng} / \mathrm{mL}$. Asian J Androl. 2005;7(3):323-8

40. Goel T, Sankhwar SN. Comparative study of zinc levels in benign and malignant lesions of the prostate. Scand J Urol Nephrol. 2006;40(2):108-12
41. Mittal R, Patel AP, Debs LH, et al. Intricate functions of matrix metalloproteinases in physiological and pathological conditions. J Cell Physiol. 2016;231(12):2599-621.

42. Price SJ, Greaves DR, Watkins $H$. Identification of novel, functional genetic variants in the human matrix metalloproteinase-2 gene: role of Sp1 in allelespecific transcriptional regulation. J Biol Chem. 2001;276(10):7549-58.

43. Jormsjö S, Whatling $\mathrm{C}$, Walter $\mathrm{DH}$, et al. Allele-specific regulation of matrix metalloproteinase-7 promoter activity is associated with coronary artery luminal dimensions among hypercholesterolemic patients. Arterioscler Thromb Vasc Biol. 2001;21(11):1834-9.

44. Van Nguyen S, Skarstedt M, Löfgren S, et al. Gene polymorphism of matrix metalloproteinase-12 and -13 and association with colorectal cancer in Swedish patients. Anticancer Res. 2013:33(8):3247-50.

45. Kita K, Miura N, Yoshida M, Yamazaki K, et al. Potential effect on cellular response to cadmium of a single-nucleotide a --> $\mathrm{G}$ polymorphism in the promoter of the human gene for metallothionein IIA. Hum Genet. 2006; 120(4):553-60.

46. Kayaalti Z, Mergen G, Söylemezoğlu T. Effect of metallothionein core promoter region polymorphism on cadmium, zinc and copper levels in autopsy kidney tissues from a Turkish population. Toxicol Appl Pharmacol. 2010:245(2):252-5.

47. Biondi ML, Turri O, Leviti S, et al. MMP1 and MMP3 polymorphisms in promoter regions and cancer. Clin Chem. 2000;46(12):2023-4.

48. Lei $H$, Hemminki $K$, Altieri $A$, et al. Promoter polymorphisms in matrix metalloproteinases and their inhibitors: few associations with breast cancer susceptibility and progression. Breast Cancer Res Treat. 2007;103(1):61-9.

49. Przybylowska K, Kluczna A, Zadrozny M, et al. Polymorphisms of the promoter regions of matrix metalloproteinases genes MMP-1 and MMP-9 in breast cancer. Breast Cancer Res Treat. 2006;95(1):65-72.

50. Zhou Y, Yu C, Miao X, et al. Substantial reduction in risk of breast cancer associated with genetic polymorphisms in the promoters of the matrix metalloproteinase-2 and tissue inhibitor of metalloproteinase-2 genes. Carcinogenesis. 2004;25(3):399-404

51. Saeed HM, Alanazi MS, Alshahrani O, et al. Matrix metalloproteinase-2 $C(-1306)$ T promoter polymorphism and breast cancer risk in the Saudi population. Acta Biochim Pol. 2013:60(3):405-9.

52. Delgado-Enciso I, Cepeda-Lopez FR, Monrroy-Guizar EA, et al. Matrix metalloproteinase-2 promoter polymorphism is associated with breast cancer in a Mexican population. Gynecol Obstet Investig. 2008;65(1):68-72.

53. Zagouri F, Sergentanis TN, Gazouli M, et al. MMP-2 -1306C >T polymorphism in breast cancer: a case-control study in a south European population. Mol Biol Rep. 2013;40(8):5035-40.

54. Roehe AV, Frazzon AP, Agnes $G$, et al. Detection of polymorphisms in the promoters of matrix metalloproteinases 2 and 9 genes in breast cancer in South Brazil: preliminary results. Breast Cancer Res Treat. 2007;102:123-4.

55. Beeghly-Fadiel A, Long JR, Gao YT, et al. Common MMP-7 polymorphisms and breast cancer susceptibility: a multistage study of association and functionality. Cancer Res. 2008;68(15):6453-9.

56. Krześlak A, Forma $E$, Jóźwiak $P$, et al. Metallothionein $2 A$ genetic polymorphisms and risk of ductal breast cancer. Clin Exp Med. 2014;14(1):107-13.

57. Liu D, Wang M, Tian T, et al. Genetic polymorphisms (rs10636 and rs28366003) in metallothionein 2A increase breast cancer risk in Chinese Han population. Aging (Albany NY). 2017;9(2):547-55.

58. Su L, Zhou W, Park S, et al. Matrix metalloproteinase-1 promoter polymorphism and lung cancer risk. Cancer Epidemiol Biomark Prev. 2005:14(3):567-70.

59. Yu C, Pan K. Xing D, et al correlation between a single nucleotide polymorphism in the matrix metalloproteinase-2 promoter and risk of lung cancer. Cancer Res. 2002;62:6430-3.

60. Zhou Y, Yu C, Miao X, et al. Functional haplotypes in the promoter of matrix metalloproteinase-2 and lung cancer susceptibility. Carcinogenesis. 2005;26: 1117-21.

61. Rollin J, Régina S, Vourc'h P, et al. Influence of MMP-2 and MMP-9 promoter polymorphisms on gene expression and clinical outcome of non-small cell lung cancer. Cancer. 2007:56(2):273-80.

62. Bayramoglu A, Gunes HV, Metintas M, et al. The association of MMP-9 enzyme activity, MMP-9 C1562T polymorphism, and MMP-2 and -9 and TIMP-1, $-2,-3$, and -4 gene expression in lung cancer. Genet Test Mol Biomarkers. 2009;13(5):671-8.

63. Hu J, Pan J, Luo ZG. MMP1 rs1799750 single nucleotide polymorphism and lung cancer risk: a meta-analysis. Asian Pac J Cancer Prev. 2012; 13(12):5981-4. 
64. Gonzalez-Arriaga P, Lopez-Cima MF, Fernandez-Somoano A, et al. Polymorphism $+17 \mathrm{c} / \mathrm{g}$ in matrix metalloprotease mmp8 decreases lung cancer risk. BMC Cancer. 2008;8:378.

65. Hinoda Y, Okayama N, Takano N, et al. Association of functional polymorphisms of matrix metalloproteinase (MMP)-1 and MMP-3 genes with colorectal cancer. Int J Cancer. 2002;102(5):526-9.

66. Ghilardi G, Biondi ML, Mangoni J, et al. Matrix metalloproteinase-1 promoter polymorphism $1 \mathrm{G} / 2 \mathrm{G}$ is correlated with colorectal cancer invasiveness. Clin Cancer Res. 2001;7(8):2344-6.

67. Saeed HM, Alanazi MS, Parine NR, et al. Matrix metalloproteinase-2 (-1306 c>t) promoter polymorphism and risk of colorectal cancer in the Saudi population. Asian Pac J Cancer Prev. 2013;14(10):6025-30.

68. Xu E, Lai $M, L \vee B$, et al. A single nucleotide polymorphism in the matrix metalloproteinase-2 promoter is associated with colorectal cancer. Biochem Biophys Res Commun. 2004:324(3):999-1003.

69. Elander N, Soderkvist P, Fransen K. Matrix metalloproteinase (MMP) -1, -2, -3 and -9 promoter polymorphisms in colorectal cancer. Anticancer Res. 2006;26(1B):791-5.

70. Kang MJ, Jung SA, Jung JM, et al. Associations between single nucleotide polymorphisms of MMP2, VEGF, and HIF1A genes and the risk of developing colorectal cancer. Anticancer Res. 2011;31(2):575-84.

71. Shalaby MA, Nounou HA, Ms A, et al. Associations between single nucleotide polymorphisms of COX-2 and MMP-2 genes and colorectal cancer susceptibility in the Saudi population. Asian Pac J Cancer Prev. 2014; 15(12):4989-94.

72. Ghilardi G, Biondi ML, Erario M, et al. Colorectal carcinoma susceptibility and metastases are associated with matrix metalloproteinase-7 promoter polymorphisms. Clin Chem. 2003:49(11):1940-2.

73. Dziki L, Przybyłowska K, Majsterek I, et al. A/G polymorphism of the MMP-7 gene promoter region in colorectal Cancer. Pol Przegl Chir. 2011;83(11):622-6.

74. de Lima JM, de Souza LG, da Silva ID, et al. E-cadherin and metalloproteinase-1 and -7 polymorphisms in colorectal cancer. Int J Biol Markers. 2009;24(2):99-106.

75. Moreno-Ortiz JM, Gutiérrez-Angulo M, Partida-Pérez M, et al. Association of MMP7-181A/G and MMP13-77A/G polymorphisms with colorectal cancer in a Mexican population. Genet Mol Res. 2014;13(2):3537-44.

76. Yang L, Li N, Wang S, et al. Lack of association between the matrix metalloproteinase-2 -1306C>T polymorphism and breast cancer susceptibility: a meta-analysis. Asian Pac J Cancer Prev. 2014;15(12):4823-7.

77. Peng B, Cao L, Ma X, et al. Meta-analysis of association between matrix metalloproteinases 2, 7 and 9 promoter polymorphisms and cancer risk. Mutagenesis. 2010;25(4):371-9.

78. Li H, Liang $X$, Qin $X$, et al. Association of matrix metalloproteinase family gene polymorphisms with lung cancer risk: logistic regression and generalized odds of published data. Sci Rep. 2015;5:10056.

79. Wu J, Guan X, Li YT, et al. Matrix metalloproteinase7 -181A/G polymorphism is associated with increased cancer risk among high-quality studies: evidence from a meta-analysis. Clin Biochem. 2013:46(16-17):1649-54.

80. Hu C, Wang J, Xu Y, et al. Current evidence on the relationship between five polymorphisms in the matrix metalloproteinases (MMP) gene and lung cancer risk: a meta-analysis. Gene. 2013;517(1):65-71,233.

81. Białkowska K, Marciniak W, Muszyńska M, et al. Association of zinc level and polymorphism in MMP-7 gene with prostate cancer in polish population. PLoS One. 2018;13(7):e0201065.

82. Vira H, Pradhan V, Umare V, et al. Role of MMP-7 in the pathogenesis of systemic lupus erythematosus (SLE). Lupus. 2017;26(9):937-43.

83. Zhang J, Jin X, Fang $S$, et al. The functional polymorphism in the matrix metalloproteinase-7 promoter increases susceptibility to esophagea squamous cell carcinoma, gastric cardiac adenocarcinoma and non-small cell lung carcinoma. Carcinogenesis. 2005;26(10):1748-53.

84. Rutter JL, Mitchell TI, Butticè $G$, et al. A single nucleotide polymorphism in the matrix metalloproteinase-1 promoter creates an ETS binding site and augments transcription. Cancer Res. 1998;58:5321-5.

85. Yoon S, Kuivaniemi H, Gatalica Z, et al. MMP13 promoter polymorphism is associated with atherosclerosis in the abdominal aorta of young black males. Matrix Biol. 2002:21(6):487-98.

\section{Publisher's Note}

Springer Nature remains neutral with regard to jurisdictional claims in published maps and institutional affiliations.

Ready to submit your research? Choose BMC and benefit from:

- fast, convenient online submission

- thorough peer review by experienced researchers in your field

- rapid publication on acceptance

- support for research data, including large and complex data types

- gold Open Access which fosters wider collaboration and increased citations

- maximum visibility for your research: over $100 \mathrm{M}$ website views per year

At $\mathrm{BMC}$, research is always in progress.

Learn more biomedcentral.com/submissions 